\title{
Open Innovation: Learning from Alliance Research
}

\author{
Joel West \\ KGI - Keck Graduate Institute \\ kgi@JoelWest.org
}

February 4, 2014

Joel West, “Open Innovation: Learning from Alliance Research,” in Refik Culpan, editor, Open Innovation Through Strategic Alliances, New York: Palgrave MacMillan, 2014, pp. 1-16

This volume examines an important area of potential research, the intersection of strategic alliances and open innovation. Although these streams of research have developed separately, with distinct assumptions and research questions, there is a natural affinity between these streams in terms of phenomena, theoretical predictions and managerial implications. As editor Refik Culpan notes in Chapter 2, both streamsassume that innovation is collaborative (and often complementary), and that such collaborations are crucial for firms to create and capture value from their innovations.

Prior research has defined strategic alliances as a cooperation agreement between two organizations. Such alliances allow organizations to pool resources, but require (inherently incomplete) contracts, trust-building measures and ongoing monitoring to limit the potential adverse impacts of imperfectly aligned interests (Gulati, 1995, 1998; Gomes-Casseres, 1996, Das, 2005). Although these alliances are typically created between two firms, companies may also form alliances with universities, nonprofit research organizations, or government laboratories (Baum et al, 2000).

Larger firms usually engage in multiple alliances with suppliers, customers and even direct competitors. An important challenge for such firms is managing the portfolio of such alliances, to assure diversity of technology or market resources, or even using competition between partners to reduce opportunism. Thus a key challenge for firms is not only managing the activities with a single partner, but also adding, deleting, and coordinating multiple partners in a portfolio (Lavie, 2007). These multiple alliances allow us to consider the role (and success) of any firm as part of a larger network of innovators, using variables such as the number of partners, their status or connectedness (Powell and Grodal, 2005).

Much of the interest in strategic alliances came from their use to spread the costs and benefits of innovation. While such alliances typically allow learning by both parties, they can create a "learning race" in which each party seeks to gain knowledge from the other party more quickly than it loses control of its own (Hamel, 1991; Hagedoorn et al, 2000; Kale et al, 2000; Hagedoorn, 2002).

It is in this interest in interfirm cooperation for innovation that alliances are relevant to open innovation - and vice versa. From the beginning, the focus of open innovation has been on such interfirm cooperation, allowing firms to improve their innovation performance by leveraging innovation creation and commercialization paths outside their firm boundaries (Chesbrough, 2003, 2006; West, Vanhaverbeke and Chesbrough, 2006).

What is open innovation? According to the latest definition by Chesbrough, it is "a distributed innovation process based on purposively managed knowledge flows across organizational boundaries, using pecuniary and non-pecuniary mechanisms in line with each organization's business model" (Chesbrough and Bogers, 2014). Research on open innovation has shown 
how firms manage both the inflows and outflows of knowledge, how they search for partners and the innovations they provide, and (to a lesser degree) how that knowledge is used after it sourced. ${ }^{1}$

Researchers have identified three distinct modes of open innovation collaboration: the inbound flows of knowledge from external sources, the outbound flows that allow firms to monetize their innovation through others, and a coupled mode that combines inbound and outbound. The inbound mode - sourcing external innovations - has thus far been the most common in research and practice, while the coupled mode corresponds to alliances for collaborative R\&D between two firms (Gassmann \& Enkel, 2004; West \& Bogers, 2014). The coupled mode subsumes two forms of collaboration. In one, bidirectional knowledge flows link the separate innovation efforts of each organization. In contrast, the interactive coupled process involves joint innovation creation beyond the boundaries of a single firm (Piller \& West, 2014).

Of course, not all alliances are about open innovation, and not all open innovation involves alliances (Table 1). Innovation alliances - those alliances involving the development or commercialization of at least one partner's innovations - would certainly qualify as a purposive, distributed innovation process across organizational boundaries. Because open innovation requires new ideas or practices "that lead to improved outcomes for an organization" (Vanhaverbeke et al, 2014), alliances that do not involve such innovation would not meet the definition of open innovation.

Even with the overlap of open innovation and innovation alliances, not all open innovation involves alliances. While alliances by definition involve working with firms (or other organizations), open innovation might also involve cooperation with individuals, communities or other levels of analysis (West et al, 2006). For example, a considerable literature has developed about how firms can use innovation tournaments to crowdsource innovations from individuals (e.g. Jeppesen \& Lakhani, 2010).

But even when the external partner is a firm, there are forms of interorganizational cooperation that can bring open innovation without alliances. By their nature, alliances involve sustained and ongoing cooperation over time (Parkhe, 1993). On the relational vs. transactional dimension (cf. Robinson et al, 1994), alliances are clearly relational (Gulati, 1995; Dyer \& Singh, 1998). However, some forms of open innovation involve isolated transactions rather ongoing relationships. One such example is the innovation contest, as with the X-Prize series of highstates innovation competitions that attract recognition far beyond the cash rewards (Ledford, 2006). And, as noted below, many platforms involve sponsors that provide technology to would-be complementors, but entail little or no direct interaction.

Thus, only a subset of open innovation involves strategic alliances: an agreement for ongoing innovation collaboration between two organizations - which closely matches the research on innovation alliances. Still, given the strong interest in $\mathrm{R} \& \mathrm{D}$ collaboration by innovation researchers over the past 25 years - and the bias of open innovation research towards firm-to-firm cooperation (West et al, 2006) - there is considerable body of overlap between these two streams.

The thirteen chapters of this book are addressed at exactly at this overlap (Table 2). Below, I summarize and organize a review of these chapters.

\section{Alliances in Open Innovation}

Both in its original conception and in its first decade of publications, open innovation research has focused on the dyadic cooperation between two firms (West et al, 2006; Vanhaverbeke et al, 2014). Thus, studying interfirm alliances 
for $R \& D$ and other innovation-relation collaboration directly corresponds to the goals and precepts of open innovation. Such studies of firm collaboration can be from the perspective of one firm or both firms, and can be at the level of the firm, the project, or the individuals involved.

\section{Antecedents and Consequences}

What are the antecedents to the success of innovation alliances and strategic alliances more broadly? This is a question that has long been studied in the alliance literature (e.g., Parkhe 1993; Doz, 1996).

In Chapter 3, Roijakkers, Bell, Fok \& Vanhaverberke examine the challenges that large multinational corporations (MNCs) face in managing external R\&D partnerships, through in-depth case studies of open innovation at two Dutch MNCs (Phillips and Shell). They identify a range of approaches to R\&D alliances, ranging from contract $R \& D$ intended to produce immediate results, through extended $R \& D$ partnerships to highly selective (and visible) strategic partnerships for joint R\&D. For the latter, they highlight the importance of multi-project collaboration agreements - incomplete contracts that make it easy to initiate new collaboration within a well-defined institutional structure.

In Chapter 4, Wubben, Meijeren \& Blok examine the alliance challenges faced by nine Dutch firms in the agriculture and chemical industries. Much as Christensen (2006) did for digital amplifiers, they examine how these firms are shifting (or helping shift) chemical feedstocks from fossil fuels to biomass, a shift that spans traditional industry boundaries and thus is facilitated through alliances with partners in complementary industries. Using interviews with a representative of each company, they identified two key measures - strategic alignment and strength of relational ties between parties - that their respondents believe lead to open innovation success.

Beyond predicting the success of an alliance strategy, one can ask the converse question: how do alliances (or successful alliances) impact the other activities of the firm?

In Chapter 5, Moreno-Menéndez \& Casillas study whether the use of alliances leads to increased internationalization. In a survey of 424 medium and large Spanish manufacturing firms, they note a strong correlation between open innovation activity and measures of internationalization, including export propensity, export intensity and foreign direct investment. By lagging the regression measures between two successive surveys, they conclude that open innovation in the earlier time period predicts increased internationalization in the later period.

\section{Collaboration with Partners}

One of the earliest questions in alliance research is how do firms manage relationships with their alliance partners (Doz, 1996; Koza \& Lewin, 1998). Two chapters in this book examine how firms work with suppliers, long identified as a crucial source of external innovations (von Hippel, 1988; Chesbrough, 2003; Gassmann et al, 2010).

In Chapter 6, Young classifies eight mini-cases of supplier-customer collaborative innovation into four quadrants based on a 2-dimensional matrix of risk and strategic importance. He concludes that product innovations only happen on the highly important dimension, but process innovations (both for production and sourcing more generally) can succeed in all quadrants. As with other research on trust in alliances (e.g., Dyer \& $\mathrm{Chu}, 2003)$, he shows how trust is essential for collaboration. More generally, he shows that a transactional view of sourcing (by cost-cutting customers) prevents the sort of relational collaboration necessary to foster such innovation.

In Chapter 7, DeFillipi, Dumas \& Bhatia examine the unique partnership between two innovative MNCs: Xerox and 
Procter \& Gamble. The collaboration served P\&G's goal of reducing costs and increasing integration by outsourcing management of printing services, and built upon Xerox's Customer-Led Integration - a form of business-to-business user innovation (cf. Bogers et al, 2010). They document the institutional structures created to lead and govern this ongoing process of collaborative innovation, and the challenges that it overcame in synchronizing the two cultures and incentives. The alliance improved throughput while reducing paper, energy and over all cost for $P \& G$, while at the same time providing solutions that Xerox could sell to other customers.

While open innovation typically focuses on collaboration between firms, universities can also be important partners for firms. Such efforts allow firms to access scientific breakthroughs, but firms face daunting challenges in aligning the incentives, goals and cultures between private gain and public science (Perkmann \& Walsh, 2007; Perkmann \& West, 2012).

In Chapter 8, Chinta \& Culpan examine the role that business-university R\&D collaborations play in a firm's overall open innovation strategy. After identifying the mutual benefits and potential conflicts between businesses and university, they consider such collaborations in the broader context of the "Triple Helix" of business, university and government (Etzkowitz \& Leydesdorff, 2000). They offer an updated technology commercialization model that points to the central role of university research in creating and developing technological inventions, and the concomitant role of the government in funding such early-stage, exploratory work.

\section{Networks and Related Forms}

Research on open innovation has considered the role of alliances, networks of alliances, and specialized forms of networks including consortia, ecosystems, platforms and communities (West, 2014).
Chapters in this book examine how firms manage two of the network forms: alliance portfolios and external ecosystems.

\section{Building and Managing Alliance Portfolios}

A given firm's portfolio of alliances defines a network of business relationships (Duysters et al, 1999). From the standpoint of the focal firm, the network is managed as a series of dyadic alliances (although these network partners may have their own alliances). How to most effectively manage such portfolios is a key theoretical and managerial issue for alliance research (cf. Ireland et al, 2002).

Two chapters consider factors that predict the success of such portfolio management.

In Chapter 9, Jelinek, Barr, Mugge \& Kouri explain how the analysis of "big data" can be used to make more systematic decisions regarding the creation and management of strategic alliances in a firm's portfolio. In particular, they consider how such decisions can overcome the cognitive limits and decision traps that bias managerial decisions. Their chapter describes an industry-funded research center at North Carolina State, and how the center has used its data analytical skills to help clients identify potential technologies, partners, markets, materials and production techniques.

In Chapter 10, Tjemkes, de Pinéda, Bahlmann, de Man \& Alexiev examine how startup firms manage upstream and downstream business relationships. They studied four young Dutch ICT services companies, half developing new technologies and the other developing new markets. They distinguish between the successful portfolio strategies for each of these strategic goals. Overall, they demonstrate how the more successful firms used a more systematic, pro-active and focused approach to build large and diverse portfolios of alliances and other business relationships. 


\section{Impacts of Networks Upon Success}

Within a given industry or region, the pattern of alliances between organizations defines a network. In the U.S., such alliances are common among firms embedded in a regional technology cluster (e.g., Owen-Smith \& Powell, 2004). In other countries, firms manage networks of captive suppliers and collaborators, as with the Japanese zaibatsu or keiretsu (Gerlach, 1992; Dyer, 1996).

In Chapter 11, Mooty \& Kedia consider the role of alliance networks upon a firm's ability to source radical innovations. Consistent with the Chesbrough (2006) open innovation funnel, they present a framework for classifying and analyzing how a firm harnesses inbound knowledge flows through the process of creating and commercializing a radical innovation. The framework considers three degrees of knowledge flows - transfer, translation and transformation - across four phases of the commercialization process: conceptualization, incubation, generation and post-generation.

In Chapter 12, Nakazono, Hikino \& Colpan consider the unique challenges for practicing open innovation by large Japanese MNCs. With high entry barriers faced by potentially innovative startups, and institutional and financial constraints that encourage a corporate grouping of related subsidiaries, these MNCs tend to practice open innovation within such groupings. In particular, consistent with open innovation, they form spinoff subsidiary firms to commercialize technologies that don't fit the business model of the parent company. They show how these constraints limited open innovation at Panasonic Corporation to new business areas that were not already deeply embedded in the group's technologies and markets.

\section{Ecosystem Management}

Finally, in some industries, networks are part of a larger pattern of interdependency of firms that is referred to as an innovation ecosystem ${ }^{2}$ (Adner, 2012; Adner \& Kapoor, 2010). A particularly kind of ecosystem often found in ICT producing industries is the platform, which combines a technical product architecture with a network of firms that make complementary products compatible with that architecture (Gawer \& Henderson, 2007; Gawer 2009).

In Chapter 13, Gencer \& Oba consider the use of external ecosystems by proprietary software companies. Noting the unique characteristics of the software artifact and institutional landscape, they contrast closed, open and hybrid innovation strategies. At different layers within a software architecture, they consider how firms answer key questions - whether, what, how and with whom of innovation partnering within each layer.

\section{Future Opportunities}

A major goal of this volume has been to bring together research on strategic alliances and open innovation. Here I offer suggestions as to how research on alliances can inform open innovation and vice versa.

\section{How Alliances Can Inform Open Innovation Research}

Researchers - both inside and outside open innovation - have expressed concern about the lack of theoretical foundations for open innovation (e.g. Vanhaverbeke et al, 2014). Open innovation is a class of phenomena - and a managerial paradigm (Chesbrough, 2006) - but it borrows causal mechanisms and theoretical predictions from other streams of economics and management research.

Research on strategic alliances has provided repeated and convergent perspectives on how organizations collaborate to pool innovation capabilities and other resources. This research has 
considered topics such as the choice of alliances versus other mechanisms, the antecedents of alliance success, aligning success between partners and other predictors of success (Koza \& Lewin, 1998). By contrasting these two streams of work, the researchers in this volume identify a number of opportunities for open innovation researchers to learn from the older and more established body of alliance research.

The internal view of partnerships. With rare exceptions (e.g. Chiaroni et al, 2010), the open innovation research tells us little about the internal organization of a firm's open innovation activities (West \& Bogers, 2014). As Chapter 3 reminds us, the alliance literature has considered these topics for decades, and thus there is an opportunity to update these insights from alliance management with the $21^{\text {st }}$ century practice of how firms manage open innovation.

Managing partnerships on an ongoing basis. The open innovation literature tends to be transactional, or at most focused on one-time collaborations. Missing is the longitudinal perspective on open innovation processes. Chapter 7 shows how the study of long-lived alliances can both provide such a longitudinal perspective, and also develop deeper insights as to the incentives, motivations and challenges of managing alliances within each side of a partnership.

Different collaboration structures. In terms of open innovation collaborations, these multi-year, strategic collaborative $R \& D$ efforts are one extreme on a continuum that includes contractual $R \& D$ as an intermediate option and a single (non-alliance) transaction at the other extreme. While different researchers have studied differing structures for open innovation collaboration, they would benefit from studying (and extending Chapter 3 ) by analyzing the variance of contracts, governance and other institutional structures within a given population.
To partner or not to partner. Open innovation tends to assume that adoption of open innovation is at the firm level rather than at the technology or project level. Alliance research has already considered what factors predict when firms chose alliances and when they don't (e.g. Hennart \& Reddy, 1997). We don't assume that a firm that has an alliance portfolio will use alliances for every project, product or technology, so why would we assume this for open innovation?

Learning from partners. Much of the first decade of alliance research focused on R\&D collaborations between large firms, such as within industry consortia or between domestic and foreign manufacturers (e.g., Hamel, 1991). A major concern of these alliances was learning and developing internal capabilities from such learning. Open innovation has been more about sourcing technology — or transferring the knowhow around a specific technology rather than developing internal capabilities. Open innovation has frequently studied absorptive capacity (West \& Bogers, 2014) but not the learning that flows from such capacity. Is this lack of study because corporate practice has changed - away from capability-building towards sourcing - or merely because no one has studied it?

Opportunism. Although learning is good for the firm doing the learning, it may not be seen as good by their alliance partner. While innovation alliances typically allow for learning by both parties, they can create a "learning race" in which each party seeks to gain knowledge from the other party more quickly than it loses control of its own (Hagedoorn, 2000, 2002; Kale et al, 2000). The questions are the same as on the previous point: are these motivations absent in open innovation, or merely unstudied?

Analysis of the network. The importance of the network perspective for understanding external firm collaborations 
has long been accepted by open innovation scholars (e.g., Vanhaverbeke \& Cloodt, 2006; West 2014). However, the tools and measures used in such studies (e.g. OwenSmith and Powell, 2004) are not. These measures and analysis techniques (such as embeddedness and social network analysis) have the potential to inform open innovation research and give it a more systematic view of how firms manage external collaborations. In particular, because open innovation distinguishes between three modes - inbound, outbound and coupled - using the directionality of knowledge flows to construct a directed graph (cf. Gloor et al, 2003) would allow that directionality to be utilized in the analysis of open innovation networks.

\section{How Open Innovation Can Inform Alliance Research}

While alliance research can inform open innovation, the converse is also true. Here I identify several opportunities for ideas of open innovation to be applied to research on strategic alliances.

Role of the business model. The business model - and the importance of aligning innovation to a firm's business model - are central to the concept of open innovation (Chesbrough, 2006); however, this precept is largely ignored in open innovation research (Chesbrough \& Bogers, 2014; West \& Bogers, 2014). Chapter 14 shows how value creation and value appropriation are crucial to understand the benefits of alliances, and such analysis could benefit from incorporating open innovation insights as to how business model experimentation links to innovation.

Small and medium sized firms. Recently, open innovation researchers have been focusing on the differences of how open innovation is practiced in small and medium enterprises (SMEs) (see Vanhaverbeke et al, 2014 for a summary). This research has identified how smaller firms approach open innovation differently, both because of their needs and capabilities, but also because of their strategies and decision processes. Alliance research (as in Chapter 7) that studies such firms could benefit from this research.

Service Innovation. Chapters 7 and 10 examine firms that are seeking to develop and commercialize innovative services, which have different mechanisms both for value creation and also creating the scarcity necessary for value capture. In a recent book, Chesbrough (2011) shows how when open innovation is applied to services, the process of open innovation is transformed to exploit customization and personalization opportunities to meet customer needs in a way that is rarely possible for tangible goods.

Leveraging ecosystems and platforms. For certain industries and classes of goods, the process of value creation and value capture are embedded in ecosystems or platforms that link the focal firm to its network of complementers (Chesbrough \& Appleyard, 2007; Rohrbeck et al 2009; West, 2014). Such ecosystems and platforms are of critical strategic importance in these industries, but strategic alliance research has largely ignored how incentives and governance are different when compare to other network forms. For example, ecosystems bring added opportunities (and stresses) for aligning the interests of alliance partners, as suggested by Chapter 13. At the same time, ecosystems (e.g. the iPhone app store) are increasingly using informal mechanisms for cooperation and complement generation, suggesting new opportunities for understanding how alliances (or cooperation more generally) is practiced without deep formal contracts.

\section{How Both Can Benefit}

In several overlapping areas, both streams are incomplete and would benefit from a deeper understanding of collaboration mechanisms and processes.

Openness strategies. Research on open source software has demonstrated how 
firms practicing open innovation benefit from a greater degree of openness (e.g., Simcoe, 2006; West \& O’Mahony, 2008). A limited amount of alliance research has considered the degree to which openness improves knowledge flows and alliance outcomes (e.g. Dyer \& Chu, 2003). However, there is still more to be studied, such as the moderators of the benefits of openness: for example, Chesbrough \& Schwartz (2007) concluded that open innovation alliances are more open when they are distant from the firm's core technologies.

The moderating effect of uncertainty. Corporate venture capital is an important mechanism for aligning the relationship between (most often) a smaller innovator and an established firm seeking inbound innovations, and can deepen the alignment of partner interests and thus the strength of alliances. These investments appear to be attractive to firms under conditions of high uncertainty (Van de Vrande et al, 2008). Meanwhile, firms can utilize equity alliances as real options to integrate external technologies into the firm (Vanhaverbeke et al, 2008).

\section{Conclusions}

The work in this volume and this chapter are meant to demonstrate the natural alignment of interests between research on open innovation and strategic alliances. Both are concerned with interorganizational cooperation and (often) both are concerned with how these organizations collaborate to create or commercialize innovations. That said, this alignment remains imperfect, and considerable work needs to be done to explore and exploit the opportunities that the overlap present.

\section{End Notes}

This chapter has been influenced by my open innovation collaborations and conversations with many scholars over the past decade, including Marcel Bogers, Henry Chesbrough, Linus Dahlander, Scott

Gallagher, Karim Lakhani, Caroline Simard, Wim Vanhaverbeke and David Wood. I want to thank editor Refik Culpan for the invitation to participate in this volume, and Wim Vanhaverbeke for his feedback on an earlier version.

1 For recent reviews of the open innovation literature, see Dahlander \& Gann (2010) West \& Bogers, (2014) and Chesbrough and Bogers (2014)

2 Some ecosystems include (or are built around) less formal interfirm relationships that don't fit the above definition of an alliance. For example, many third party developers for personal computing (Apple, Microsoft), open source (Linux) and Software as a Service platforms (Google, Yahoo) develop their complementary goods without a contractual relationship with the platform sponsor, to the degree that the sponsor does not know the full list of its ecosystem members. 


\section{References}

Adner, Ron (2012) The wide lens: A new strategy for innovation, New York: Penguin.

Adner, Ron, and Rahul Kapoor. 2010. "Value creation in innovation ecosystems: how the structure of technological interdependence affects firm performance in new technology generations." Strategic Management Journal 31 (3): 306-333.

Baum, Joel AC, Tony Calabrese, and Brian S. Silverman. 2000. "Don't go it alone: Alliance network composition and startups' performance in Canadian biotechnology." Strategic Management Journal 21 (3): 267-294.

Bogers, Marcel, Afuah, Allan and Bastian, Bettina. (2010). "Users as innovators: A review, critique, and future research directions," Journal of Management, 36(4): 857-875.

Chesbrough, Henry. 2003. Open Innovation: The New Imperative for Creating and Profiting from Technology. Harvard Business School Press, Boston.

Chesbrough, Henry (2006) "Open innovation: A new paradigm for understanding industrial innovation," in Henry Chesbrough, Wim Vanhaverbeke, and Joel West, eds., Open Innovation: Researching a New Paradigm. Oxford: Oxford University Press, pp. 1-12.

Chesbrough, Henry. 2011. Open Services Innovation: Rethinking Your Business to Grow and Compete in a New Era. San Francisco: Jossey-Bass.

Chesbrough, Henry W. \& Melissa M. Appleyard,. (2007). Open Innovation and Strategy. California Management Review, 50 (1), 57-76.

Chesbrough, Henry \& Marcel Bogers 2014. "Explicating Open Innovation: Clarifying an Emerging Paradigm for Understanding Innovation" in Henry Chesbrough, Wim Vanhaverbeke and Joel West, eds., Open Innovation: New Frontiers and Applications, Oxford: Oxford University Press, 2014.

Chesbrough, Henry, and Kevin Schwartz. "Innovating business models with co-development partnerships." Research-Technology Management 50, no. 1 (2007): 55-59.

Chiaroni, Davide, Chiesa, Vittorio and Frattini, Federico. (2010). 'Unraveling the process from Closed to Open Innovation: evidence from mature, asset-intensive industries', $R \& D$ Management 40 (3): 222-245

Christensen, Jens Frøslev. 2006. "Wither Core Competency for the Large Corporation in an Open Innovation World?" in Henry Chesbrough, Wim Vanhaverbeke, and Joel West, eds., Open Innovation: Researching a New Paradigm. Oxford: Oxford University Press, pp. 35-61.

Dahlander, Linus, and David M. Gann, 2010. "How Open Is Innovation?” Research Policy 39 (6), 699-709.

Das, T. K. 2005 "Deceitful behaviors of alliance partners: potential and prevention." Management Decision 43, (5): 706-719.

Doz, Yves L. 1996. "The evolution of cooperation in strategic alliances: initial conditions or learning processes?" Strategic Management Journal 17 (S1): 55-83.

Duysters, Geert, Ard-Pieter De Man, and Leo Wildeman. 1999. "A network approach to alliance management.” European Management Journal 17 (2): 182-187.

Dyer, Jeffrey H. 1996. "Does governance matter? Keiretsu alliances and asset specificity as sources of Japanese competitive advantage." Organization Science 7 (6): 649-666.

Dyer, Jeffrey H., and Wujin Chu. "The role of trustworthiness in reducing transaction costs and improving performance: Empirical evidence from the United States, Japan, and Korea." Organization Science 14, no. 1 (2003): 57-68.

Dyer, Jeffrey H., and Harbir Singh.1998, "The relational view: Cooperative strategy and sources of interorganizational competitive advantage." Academy of Management Review 23 (4): 660-679. 
Etzkowitz, Henry, and Loet Leydesdorff. 2000 "The dynamics of innovation: from National Systems and "Mode 2" to a Triple Helix of university-industry-government relations." Research Policy 29 (2): 109-123.

Gassmann, Oliver, and Ellen Enkel. 2004 "Towards a theory of open innovation: three core process archetypes." R\&D Management Conference, Lisbon July 6-9.

Gassmann, Oliver, Enkel, Ellen, Chesbrough, Henry. 2010. "The future of open innovation," $R \&$ D Management 40 (3): 213-221.

Gawer, Annabelle (2009). "Platform dynamics and strategies: from products to services," In Annabelle Gawer, ed., Platforms, Markets and Innovation, Cheltenham, UK: Edward Elgar,

Gawer, Annabelle, and Rebecca Henderson. 2007. "Platform owner entry and innovation in complementary markets: Evidence from Intel." Journal of Economics \& Management Strategy 16 (1): 1-34.

Gerlach, Michael L. 1992. "The Japanese corporate network: A blockmodel analysis." Administrative Science Quarterly, 105-139.

Gloor, Peter A., Rob Laubacher, Scott BC Dynes, and Yan Zhao. 2003 "Visualization of communication patterns in collaborative innovation networks-analysis of some w3c working groups." In Proceedings of the twelfth international conference on Information and knowledge management, ACM, pp. 56-60.

Gomes-Casseres, Benjamin (1996) The Alliance Revolution: The New Shape of Business Rivalry, Boston: Harvard Business School Publishing.

Gulati, Ranjay. 1995. "Does familiarity breed trust? The implications of repeated ties for contractual choice in alliances." Academy of Management Journal 38 (1): 85-112.

Gulati, Ranjay. 1998. “Alliances and networks.” Strategic Management Journal 19 (4): 293317.

Hagedoorn, John. 2002. "Inter-firm R\&D partnerships: an overview of major trends and patterns since 1960." Research Policy 31 (4): 477-492.

Hagedoorn, John, Albert N. Link, and Nicholas S. Vonortas. 2000. "Research partnerships." Research Policy 29 (4): 567-586.

Hamel, Gary. 1991 "Competition for competence and interpartner learning within international strategic alliances.” Strategic Management Journal 12 (S1): 83-103.

Hennart, Jean-Francois, and Sabine Reddy. "The choice between mergers/acquisitions and joint ventures: The case of Japanese investors in the United States." Strategic Management Journal 18, no. 1 (1997): 1-12.

Ireland, R. Duane, Michael A. Hitt, and Deepa Vaidyanath. "Alliance management as a source of competitive advantage." Journal of Management 28, no. 3 (2002): 413-446.

Jeppesen, Lars Bo, and Karim R. Lakhani. 2010 "Marginality and problem-solving effectiveness in broadcast search." Organization Science 21, (5): 1016-1033.

Kale, Prashant, Harbir Singh, and Howard Perlmutter. 2000 "Learning and protection of proprietary assets in strategic alliances: building relational capital." Strategic Management Journal 21 (3): 217-237.

Koza, Mitchell P., and Arie Y. Lewin. (1998). "The co-evolution of strategic alliances." Organization Science 9 (3): 255-264.

Lavie, Dovev. 2007. "Alliance portfolios and firm performance: A study of value creation and appropriation in the US software industry." Strategic Management Journal 28 (12): 1187-1212.

Ledford, Heidi. 2006. "Kudos, not cash, is the real X-factor." Nature 443 (7113): 733.

Owen-Smith, Jason, and Walter W. Powell. 2004. "Knowledge networks as channels and conduits: The effects of spillovers in the Boston biotechnology community."

Organization Science 15 (1): 5-21. 
Parkhe, Arvind. 1993. "Strategic alliance structuring: A game theoretic and transaction cost examination of interfirm cooperation." Academy of Management Journal 36 (4): 794-829.

Perkmann, Markus, and Kathryn Walsh. 2007. "University-industry relationships and open innovation: Towards a research agenda." International Journal of Management Reviews 9, (4): 259-280.

Perkmann, Markus, and Joel West. 2012. "Open science and open innovation: sourcing knowledge from universities." Available at SSRN: http://ssrn.com/abstract=2133397

Piller, Frank and Joel West. 2014. "Firms, Users, and Innovation: An Interactive Model of Coupled Open Innovation.” in Henry Chesbrough, Wim Vanhaverbeke and Joel West, eds., Open Innovation: New Frontiers and Applications, Oxford: Oxford University Press, 2014.

Powell, Walter W., and Stine Grodal. 2005. "Networks of innovators." In Jan Fagerberg, David C. Mowery and Richard R. Nelson, editors, The Oxford Handbook of Innovation, Oxford: Oxford University Press, pp. 56-85.

Robinson, Sandra L, Matthew S. Kraatz and Denise M. Rousseau, 1994. "Changing Obligations and the Psychological Contract: A Longitudinal Study," Academy of Management Journal, 37 (1), pp. 137-152.

Rohrbeck, René, Katharina Hoelzle, and Hans Georg Gemünden. 2009.”Opening up for competitive advantage-How Deutsche Telekom creates an open innovation ecosystem." $R \& d$ Management 39 (4): 420-430.

Simcoe, Tim (2006) "Open Standards and Intellectual Property Rights," in Henry Chesbrough, Wim Vanhaverbeke, and Joel West, eds., Open Innovation: Researching a New Paradigm. Oxford: Oxford University Press, pp. 161-183.

van de Vrande, Vareska, Wim Vanhaverbeke \& Geert Duysters, (2009). External technology sourcing: the effect of uncertainty on governance mode choice. Journal of Business Venturing, 24(1), 62-80.

Vanhaverbeke, Wim, and Myriam Cloodt. "Open innovation in value networks." in Henry Chesbrough, Wim Vanhaverbeke, and Joel West, eds., Open Innovation: Researching a New Paradigm. Oxford: Oxford University Press, pp. 258-281.

Vanhaverbeke, Wim, Vareska van de Vrande, \& Henry Chesbrough (2008). Understanding the advantages of open innovation practices in corporate venturing in terms of real options. Creativity and Innovation Management, 17(4), 251-258.

Vanhaverbeke, Wim, Joel West, and Henry Chesbrough (2014) "Surfing the new wave of open innovation research" in Henry Chesbrough, Wim Vanhaverbeke and Joel West, eds., Open Innovation: New Frontiers and Applications, Oxford: Oxford University Press, 2014.

von Hippel, Eric, (1988). The Sources of Innovation. New York: Oxford University Press. West, Joel. 2014 "Challenges of Funding Open Innovation Platforms: Lessons from Symbian Ltd." in Henry Chesbrough, Wim Vanhaverbeke and Joel West, eds., Open Innovation: New Frontiers and Applications, Oxford: Oxford University Press, 2014.

West, Joel and Marcel Bogers. 2014. Profiting from External Innovation: A Review of Research on Open Innovation. Journal of Product Innovation Management.

West, Joel and Siobhán O’Mahony. 2008. "The role of participation architecture in growing sponsored open source communities," Industry \& Innovation, 15 (2): 145-168.

West, Joel, Wim Vanhaverbeke and Henry Chesbrough (2006) "Open Innovation: A Research Agenda," in Henry Chesbrough, Wim Vanhaverbeke, and Joel West, eds., Open Innovation: Researching a New Paradigm. Oxford: Oxford University Press, pp. 285307. 


\section{Chapters in the Book}

Refik Culpan, Open Innovation Business Models and the Role of Inter-firm Partnerships, Chapter 2 in Refik Culpan, editor, Open Innovation Through Strategic Alliances, New York: Palgrave MacMillan, 2014.

Nadine Roijakkers, John Bell, Jaco Fok \& Wim Vanhaverberke, Open Innovation through R\&D Partnerships: Implementation Issues and Routes to Success, Chapter 3 in Refik Culpan, editor, Open Innovation Through Strategic Alliances, New York: Palgrave MacMillan, 2014.

Emiel F.M. Wubben, Andre van Meijeren, Vincent Blok, Relational Drivers of Open innovation alliances in biochemistry? Chapter 4 in Refik Culpan, editor, Open Innovation Through Strategic Alliances, New York: Palgrave MacMillan, 2014.

Moreno-Menéndez, Ana M. and Jose C. Casillas, Open Innovation and Internationalization Behavior: The Case Of Spanish Firms, Chapter 5 in Refik Culpan, editor, Open Innovation Through Strategic Alliances, New York: Palgrave MacMillan, 2014.

Richard R. Young, Accessing Innovation in Supply Chains, Chapter 6 in Refik Culpan, editor, Open Innovation Through Strategic Alliances, New York: Palgrave MacMillan, 2014.

Robert DeFilippi, Colette Dumas \& Sushil Bhatia, Genesis and Evolution of the Xerox P\&G Co-Innovation Partnership: Lessons Learned, Chapter 7 in Refik Culpan, editor, Open Innovation Through Strategic Alliances, New York: Palgrave MacMillan, 2014.

Ravi Chinta and Refik Culpan, The Role of Open Innovation in Business-University R\&D Collaborations, Chapter 8 in Refik Culpan, editor, Open Innovation Through Strategic Alliances, New York: Palgrave MacMillan, 2014.

Mariann Jelinek, Steve Barr, Paul Mugge, and Richard Kouri, The Big Data Lever for Strategic Alliances. Chapter 9 in Refik Culpan, editor, Open Innovation Through Strategic Alliances, New York: Palgrave MacMillan, 2014.

Brian Tjemkes, Eduard H. de Pinéda, Marc D. Bahlmann, Ard-Pieter de Man, Alexander Alexiev. Open Innovation and KIBS Startups: Technology- and Market-Based Alliance Portfolio Configurations, Chapter 10 in Refik Culpan, editor, Open Innovation Through Strategic Alliances, New York: Palgrave MacMillan, 2014.

Mehmet Gencer \& Beyza Oba, Open Innovation Ecosystems in the Software Industry, Chapter 11 in Refik Culpan, editor, Open Innovation Through Strategic Alliances, New York: Palgrave MacMillan, 2014.

Scott Mooty \& Ben Kedia, R\&D Partnership Portfolio Strategies for Breakthrough Innovation: Developing Knowledge Exchange Capabilities. Chapter 11 in Refik Culpan, editor, Open Innovation Through Strategic Alliances, New York: Palgrave MacMillan, 2014.

Hiroyuki Nakazono, Takashi Hikino \& Asli M. Colpan, Corporate Groups and Open Innovation: The Case of Panasonic in Japan. Chapter 12 in Refik Culpan, editor, Open Innovation Through Strategic Alliances, New York: Palgrave MacMillan, 2014.

Refik Culpan, Challenges and Prospects of Strategic Alliances for Open Innovation, Chapter 14 in Refik Culpan, editor, Open Innovation Through Strategic Alliances, New York: Palgrave MacMillan, 2014. 
Figures and Tables

\begin{tabular}{l|l|l} 
& Open Innovation & Non-Innovation Cooperation \\
\hline Strategic Alliances & Innovation alliances & Other alliances \\
\hline $\begin{array}{l}\text { Interorganizational } \\
\text { Transactions }\end{array}$ & Innovation contests & $\begin{array}{l}\text { Procurement of commodities and } \\
\text { standardized components }\end{array}$
\end{tabular}

Table 1: Forms of interorganizational cooperation

\begin{tabular}{|c|c|c|c|}
\hline Chapter & Authors & $\begin{array}{l}\text { Level of } \\
\text { Analysis }\end{array}$ & Key Question \\
\hline 2. & Culpan & all & $\begin{array}{l}\text { How do alliances enable the practice of } \\
\text { open innovation? }\end{array}$ \\
\hline 3. & $\begin{array}{l}\text { Roijakkers, Bell, Fok } \\
\text { \& Vanhaverberke }\end{array}$ & alliance & $\begin{array}{l}\text { What challenges do MNCs face } \\
\text { implementing external R\&D } \\
\text { collaborations? }\end{array}$ \\
\hline 4. & $\begin{array}{l}\text { Wubben, Meijeren \& } \\
\text { Blok }\end{array}$ & alliance & $\begin{array}{l}\text { What are the relational drivers of } \\
\text { successful innovation collaboration } \\
\text { between industries? }\end{array}$ \\
\hline 5. & $\begin{array}{l}\text { Moreno-Menéndez \& } \\
\text { Casillas }\end{array}$ & alliance & $\begin{array}{l}\text { Does openness in innovation lead to } \\
\text { increased internationalization? }\end{array}$ \\
\hline 6. & Young & alliance & $\begin{array}{l}\text { How do firms collaboratively innovate } \\
\text { with their supply chain to improve } \\
\text { performance? }\end{array}$ \\
\hline 7. & $\begin{array}{l}\text { DeFillipi, Dumas \& } \\
\text { Bhatia }\end{array}$ & alliance & $\begin{array}{l}\text { How do a customer and supplier create a } \\
\text { relational alliance that enables an ongoing } \\
\text { process of collaborative innovation? }\end{array}$ \\
\hline 8. & Chinta \& Culpan & alliance & $\begin{array}{l}\text { What role do university alliances play in } \\
\text { open innovation strategies? }\end{array}$ \\
\hline 9. & $\begin{array}{l}\text { Jelinek, Barr, Mugge } \\
\text { \& Kouri }\end{array}$ & network & $\begin{array}{l}\text { How can big data overcome cognitive } \\
\text { limits in managing alliance networks? }\end{array}$ \\
\hline 10. & $\begin{array}{l}\text { Tjemkes, de Pinéda, } \\
\text { Bahlmann, de Man \& } \\
\text { Alexiev }\end{array}$ & network & $\begin{array}{l}\text { How does the approach to building a } \\
\text { portfolio of alliances impact the benefits } \\
\text { of the portfolio? }\end{array}$ \\
\hline 11. & Mooty \& Kedia & network & $\begin{array}{l}\text { How can alliance networks support } \\
\text { inbound open innovation for breakthrough } \\
\text { innovation? }\end{array}$ \\
\hline 12. & $\begin{array}{l}\text { Nakazono, Hikino \& } \\
\text { Colpan }\end{array}$ & network & $\begin{array}{l}\text { How do routines and network } \\
\text { embeddedness prevent firms from opening } \\
\text { up their innovation processes? }\end{array}$ \\
\hline 13. & Gencer \& Oba & ecosystem & $\begin{array}{l}\text { How do ecosystems and other forms of } \\
\text { external collaboration enable open } \\
\text { innovation in the software industry? }\end{array}$ \\
\hline 14. & Culpan & all & $\begin{array}{l}\text { How do decisions about alliances impact } \\
\text { the broader success of open innovation? }\end{array}$ \\
\hline
\end{tabular}

Table 2: Key questions posed by each chapter 